\title{
Comparison of the development of proteolytic activity in the abomasum of the preruminant calf with that in the stomach of the young rabbit and guinea-pig
}

\author{
BY M. J. HENSCHEL \\ National Institute for Research in Dairying, Shinfield, Reading $R G 2{ }_{9} A T$ \\ (Received I9 October $1972-$ Accepted 30 Fanuary 1973)
}

\begin{abstract}
I. Proteolytic activity was measured in the abomasal contents of five calves during the first 7 weeks of life and in the stomach contents of rabbits and guinea-pigs during the first 4 weeks of life.

2. The pattern of protease secretion in the abomasum varied considerably among individual calves; in addition to rennin, some pepsin activity was found in most animals from the first sampling at $9 \mathrm{~d}$ of age.

3. Only pepsin was secreted in the guinea-pig stomach from birth, at a consistently high level at all ages.

4. The main peak of proteolytic activity in the rabbit stomach during the ist week post partum had an optimum at $\mathrm{pH}_{3} \cdot 5-4 \cdot 0$, corresponding to that for calf rennin. During the 3 rd week of life the main pepsin peak, with an optimum at $\mathrm{pH} \times \cdot 6-2 \cdot 0$, developed.

5. Agarose gel electrophoresis of an extract of neonatal rabbit stomach mucosa showed the activity peak at $\mathrm{pH}_{3} \cdot 5^{-4} \cdot \mathrm{o}^{\circ}$ to be due to two slow-moving components of mobilities similar to that of crystalline rennin. At least one of these cross-reacted with antiserum to crystalline rennin.

6. At $\mathrm{I} 0 \mathrm{~d}$ and 3 weeks of age, activity at $\mathrm{pH} \mathbf{r} \cdot 6-2 \cdot 0$ was due to two faster-moving proteases, one being the main pepsin of the adult rabbit, which moved at the same speed as crystalline porcine pepsin, with the antiserum of which it cross-reacted.
\end{abstract}

Differences exist between species in the development of protease secretions in the neonate (see reviews by Turner, Miller \& Segal, 1967, and by Deren, 1971). They may have arisen as a result of the great inter-species differences in the protein composition of maternal milks, but an alternative explanation may be that the young of different species are born at different stages of development, from the immaturity of the rat or rabbit to the relative maturity of the guinea-pig. The calf is born when it is at a stage between these extremes, as it is able to stand and walk soon after birth yet is dependent upon a diet of milk for some weeks afterwards.

Although digestion in the calf has been widely studied, conflicting evidence exists, especially regarding the enzymic development of the abomasal secretion. Berridge, Davis, Kon, Kon \& Spratling (1943) postulated that the changeover from rennin to pepsin secretion is initiated when the animal first starts to eat roughage, a view not shared by Henschel, Hill \& Porter (I96r), who studied three milk-fed, muzzled calves and found that two secreted some pepsin from the start of the investigation when the calves were $\mathbf{I}-\mathbf{2}$ weeks of age.

The present paper describes further studies on the development with age of proteolytic activity in the preruminant abomasums of five calves and provides a comparison with results obtained for neonates of two species of laboratory animal, the guinea-pig and the rabbit. In earlier work, Henschel \& Porter (I96I) reported finding pepsin 
only in the guinea-pig stomach from birth to 4 weeks of age. In contrast, Deren (I97I) stated that pepsin secretion was extremely slow to develop in the young rabbit.

\section{EXPERIMENTAL}

\section{Animals}

Calves. Two Shorthorn and three Ayrshire male calves were separated from their dams immediately after birth. Colostrum was given for two feeds during the first $24 \mathrm{~h}$ of life, followed by one feed of a colostrum-milk mixture, after which the diet consisted of cow's milk alone. The animals were muzzled between feeds until the end of the sampling period. Between the ages of 3 and $7 \mathrm{~d}$ each calf was fistulated and a cannula was inserted into the abomasum. The calf was then allowed $2-5 \mathrm{~d}$ for recuperation before sampling began.

Guinea-pigs. The guinea-pigs were cross-bred from English and Abyssinian stock and were kept with the sows until killed. Weaning took place naturally.

Rabbits. The rabbits were the progeny of New Zealand White parents. All were kept with their respective does and allowed to suckle freely until killed. Weaning usually occurred during the $3^{\text {rd }}$ and 4 th weeks of life.

\section{Sampling procedures}

Calves. Samples of abomasal contents were taken from each calf on one day during the 2 nd, $4^{\text {th }}$ and $7^{\text {th }}$ wceks of life (mean ages 9, 26 and $47 \mathrm{~d}$ ). About $100 \mathrm{ml}$ were removed immediately before and $30 \mathrm{~min}$ after the morning feed and stored at $4^{\circ}$ in a refrigerator. Froteolytic activity was measured on the day of sampling.

Guinea-pigs. The guinea-pigs were killed with diethyl ether at weekly intervals in age groups from birth to 4 weeks. Each group contained from ten to fifteen animals from at least eight litters.

The whole stomachs were removed, weighed, blended twice with acetone at $0^{\circ}$, dried in air at room temperature, re-weighed and stored under desiccation at $4^{\circ}$.

Rabbits. Representatives of at least four different litters were killed with diethyl ether at weekly intervals from birth to 4 weeks of age about $6 \mathrm{~h}$ after feeding. Each age-group consisted of between six and eight rabbits. For comparison, two adults aged 18 months were killed by a blow to the back of the head.

With the exception of those from the neonatal rabbits, each stomach was quickly removed and a cut made from the pylorus to the cardia. Careful eversion of the stomach wall enabled the contents, in the form of a hard clot, to be removed cleanly, so that washing of the stomach lining was not necessary. The walls and contents were weighed separately and stored at $-20^{\circ}$ until required. The stomachs of the neonates were not treated in this way since they contained only a small quantity of chyme: they were weighed in toto and stored with the other samples at $-20^{\circ}$.

\section{Analytical methods}

Although haemoglobin is the substrate usually used for the in vitro estimation of protease activity by tyrosine release (Anson, I939), casein was preferred for two 
reasons. First, it is the main dietary protein of the infant mammal and therefore digestion in vitro using this substrate should be more nearly similar to that in vivo; secondly, casein provides better separation of the peaks of optimal activity of pepsin and rennin than does haemoglobin.

Preparation of substrate. To offset variations in the composition of casein from different samples of milk, a single batch of $75^{\circ} \mathrm{g}$ dry casein, prepared from the bulked milk of cows in mid-lactation by the single, slow-precipitation method of Van Slyke \& Baker (1918), was used for all estimations.

Substrates consisting of $20 \mathrm{~g}$ casein/l of $O \cdot \mathrm{I} \mathrm{M}$-citric acid, adjusted to a range of $\mathrm{pH}$ from $\mathrm{I} \cdot 0$ to $5^{\circ} \mathrm{O}$ in steps of 0.2 units, were prepared. All $\mathrm{pH}$ measurements and adjustments were made with the aid of a Radiometer (Radiometer A/S, Copenhagen, Denmark) $28 \mathrm{pH}$ meter.

Measurement of proteolysis. For each sample, four volumes of $\mathrm{x} \cdot 5 \mathrm{ml}$ were withdrawn from the substrates at each $\mathrm{pH}$ and placed in test-tubes, one for a blank, two for hydrolysis and a fourth for measurement of the $\mathrm{pH}$ of the digestion mixture. Each sample of stomach wall, stomach contents or whole stomach was homogenized in and appropriately dilutcd with ice-cold $0.0 \mathrm{M} \mathrm{M}-\mathrm{HCl}$. This and one complete set of substrate tubes were brought separately to $37^{\circ}$ in a water-bath, $5.0 \mathrm{ml}$ of an aqueous trichloroacetic acid (TCA) solution containing $75 \mathrm{~g}$ TCA $/ 1$ were added to each blank, and then all tubes received $\mathrm{r} \cdot \mathrm{O} \mathrm{ml}$ of the diluted homogenate. 'The mixtures for $\mathrm{pH}$ measurement were removed immediately and measurements made concurrently with digestion in the duplicates, which was stopped after 15 min by the addition of $5.0 \mathrm{ml} \mathrm{TCA}$ solution to each tube. The precipitates were removed by filtration through Whatman no. 542 paper, and the optical density of the filtrates was read on a Unicam SP 500 spectrophotometer against the blanks at $278 \mathrm{~nm}$ and compared with that of a tyrosine standard.

Activity was expressed as mequiv. tyrosine residues soluble in a final solution containing $0.375 \mathrm{~g} \mathrm{TCA} / 7.5 \mathrm{ml}$ released per min per $\mathrm{g}$ whole stomach or stomach contents at $37^{\circ}$.

\section{Identification of rabbit stomach proteases}

Scrapings of mucosa were taken from the whole-stomach walls of individual rabbits killed at birth, at Io d, 3 weeks and I 8 months of age. All scrapings were taken on an ice-cold surface and were stored at $-20^{\circ}$ until required. For the tests, each sample was homogenized with three times its weight of ice-cold o.or M-HCl.

Electrophoresis. The extracts were subjected to electrophoresis in agarose gel by the technique of Uriel ( 1960$)$. Photographic cover glasses $815 \mathrm{~mm}$ square were coated with an even layer of agarose gel $\mathrm{I}$ mm thick, prepared by dissolving $\mathrm{I} g$ agarose (Seravac Laboratories (Pty) Ltd, Holyport, Maidenhead, Berks) in I0o $\mathrm{ml}$ of a buffer containing $0.05 \mathrm{M}$-sodium diethyl barbiturate and $0.01 \mathrm{M}$-EDTA disodium salt, $\mathrm{pH} 8 \cdot 6$. Samples were applied $20 \mathrm{~mm}$ from the cathode pole and run for $\mathrm{I} \cdot 5 \mathrm{~h}$ at a potential of $75 \mathrm{~V}(0.9 \mathrm{~V} / \mathrm{mm})$ at room temperature. The plates were then flooded with a substrate of $2 \mathrm{~g}$ casein in $100 \mathrm{ml} \mathrm{O} \cdot \mathrm{I} \mathrm{M}$-citric acid, adjusted to $\mathrm{pH} 2 \cdot 0$, and incubated for $2.5 \mathrm{~h}$ at $37^{\circ}$, after which the undigested protein was fixed with TCA solution 


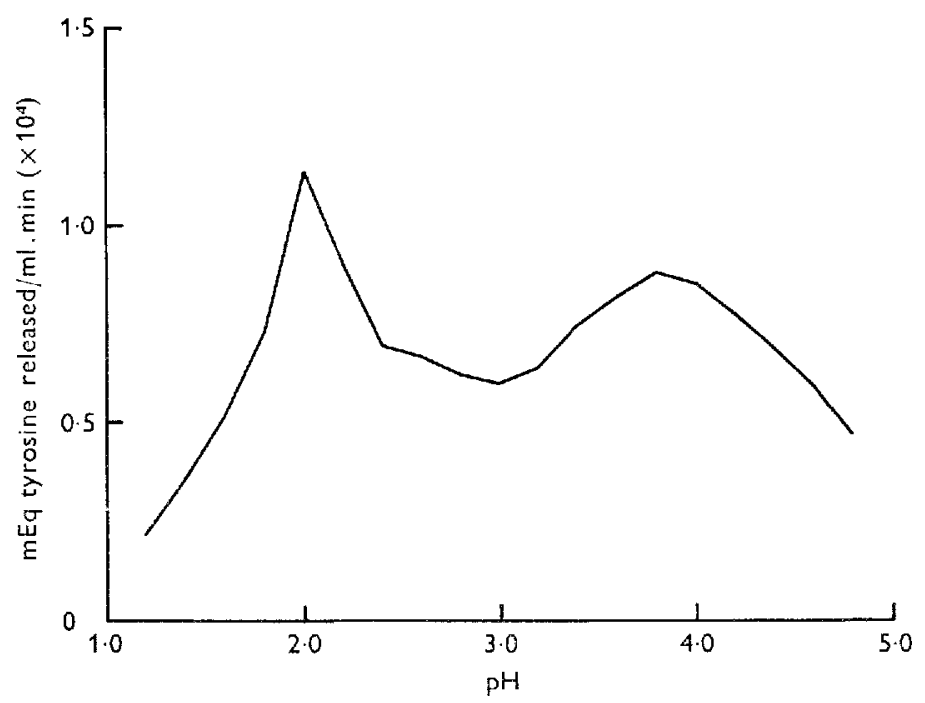

Fig. I. pH-activity curves for a mixture of crystalline pepsin and rennin.

containing $7.5 \mathrm{~g} / \mathrm{I} 00 \mathrm{ml}$ and stained with Amido Black. Samples of crystalline porcine pepsin (Koch-Light Laboratories Ltd, Colnbrook, Bucks) and crystalline rennin, prepared in the laboratory by the method of Berridge \& Woodward (1953), were run at the same time as the extracts.

Much confusion exists in the literature concerning the identification and nomenclature of the different pepsins. The system which is probably the most relevant, and which is adopted here, is that of Etherington \& Taylor (1967), in which the electrophoretic components of gastric juice are numbered in descending order of mobility from I to 7 , the main (fundic) pepsin being no. 3 , pyloric pepsin, no. 5, and rennin, which is in the slowest-moving position, no. 7 .

Immuno-diffusion. The antigenic activity of the samples was too low for successful immuno-electrophoresis, and immuno-chemical tests were made by the more sensitive but less diagnostic, microimmuno-double diffusion technique against rabbit antiserums for crystalline porcine pepsin and crystalline rennin. Diffusion was carried out at $\mathrm{pH} 8.6$ in the agarose gel described above.

\section{RESULTS}

Crystalline enzymes. The $\mathrm{pH}$-activity curve for a mixture of crystalline pepsin and rennin is shown in Fig. I. A sharp peak due to pepsin was obtained at $\mathrm{pH} 2 \cdot 0$, whereas the peak due to rennin was flatter, with an optimum at $\mathrm{pH} 3 \cdot 8$.

Proteolytic activity of calf abomasal contents. Wide variation was seen in the secretion of the gastric proteases in each of the five calves studied (Fig. 2A-F). One Ayrshire calf had little or no pepsin activity, either before or after feeding, for the whole period, whereas another secreted predominately pepsin throughout. In the third Ayrshire calf, pepsin was secreted almost exclusively during the 2nd week of life, 
but at the end of the period mostly rennin activity was found. The two Shorthorn calves secreted pepsin and rennin throughout the experimental period.

Proteolytic activity of guinea-pig stomachs. The pattern of activity was almost identical at all ages from birth to 3 weeks. Fig. 3 shows the mean $\mathrm{pH}$-activity curves for each age-group. Except for a slight inflexion of the curve at about $\mathrm{pH}_{3.5}$ in the samples obtained at birth and I week of age, consistently high activity was observed only at the $\mathrm{pH}$ optimum of pepsin.

Proteolytic activity of rabbit stomachs and stomach contents. The mean $\mathrm{pH}$-activity curves for the whole stomachs of the seven neonates are shown in Fig. 4. Those for the stomach contents of individual members of each litter represented in the four groups from I to 4 weeks of age are shown in Fig. $5 \mathrm{~A}-\mathrm{D}$.

At birth the main activity peak for the whole stomach homogenates lay between $\mathrm{pH}_{3.5}$ and $4{ }^{\circ}$, corresponding to that for crystalline rennin. At $\mathrm{I}$ week of age (Fig. $5 \mathrm{~A}$ ) maximal proteolytic activity in the contents was in the $\mathrm{pH}$ ranges $\mathrm{I} \cdot 6-2 \cdot 0$ and $3^{\cdot} \mathrm{I}-3^{\cdot} \cdot 6$. By the end of the 2 nd week of life (Fig. $5 \mathrm{~B}$ ), activity at $\mathrm{pH} \mathrm{r} \cdot 6-2 \cdot 0$, corresponding to crystalline pepsin, had increased in all samples to become dominant over that at $\mathrm{pH} 3 \cdot \mathrm{I}-3 \cdot 6$ although some evidence of an activity peak at the higher $\mathrm{pH}$ persisted throughout. After the age of 3 weeks (Fig. $5 \mathrm{C}, \mathrm{D}$ ) there was little change in the pattern of secretion, the mean curves (Fig. 6) closely resembling those for the adult rabbit whole stomachs.

\section{Characterization of rabbit pepsins}

Agarose gel electrophoresis. Pl. I shows that the neonatal rabbit mucosal extract (B) gave two main components which corresponded in position to Etherington \& Taylor's ( 1967 ) pepsins 7 and 6. The sample of crystalline rennin (A) gave a more diffuse spot covering both these positions. From mucosa taken during the 2nd week of life (C) when the transition from an optimum at a mean $\mathrm{pH}$ of 3.8 to one at $\mathrm{pH}$. .8 was taking place, enzyme components were seen which corresponded not only to 'pepsins' 7 and 6 , but also to two in positions 5 and 3 , no. 5 being dominant to no. 3 . Most of the proteolytic activity of the sample from the adult rabbit stomach $(F)$ was found in position 3, which ran at the same speed as the porcine pepsin marker (D). Some activity was also still apparent in positions 6 and 7 . It is uncertain whether the 'tailing' above the no. 3 position in $\mathrm{D}$ and $\mathrm{F}$ was due to a component in position 4 , which Etherington \& Taylor (1967) suggested was probably due to a complex between pepsin 3 and an inhibitor. The pattern of activity obtained with the mucosal extract from a 3-week-old rabbit (E) showed that the characteristic pepsin of the adult rabbit had not yet developed fully, the main activity being in position 5 .

Interpretation of these results in the light of the $\mathrm{pH}$-activity curves indicates that pepsins 3 and 5 had a $\mathrm{pH}$ optimum of $\mathrm{I} \cdot 6-2 \cdot 0$, whereas 6 and 7 had an optimum of $\mathrm{pH} 3 \cdot 5-4 \cdot 0$.

Immuno-diffusion. Standard solutions of pepsin ( $\mathrm{Pl}$. 2A, spots 4-6) and rennin (P1. 2 B, spots 4-6) gave good reactions against their own antiserums, but the highest level of each (Pl. $2 \mathrm{~A}$ and $2 \mathrm{~B}$, spot 3 ) did not cross-react with the antiserum of the other. The extract of the adult stomach mucosa (both plates, spot 2) precipitated only 

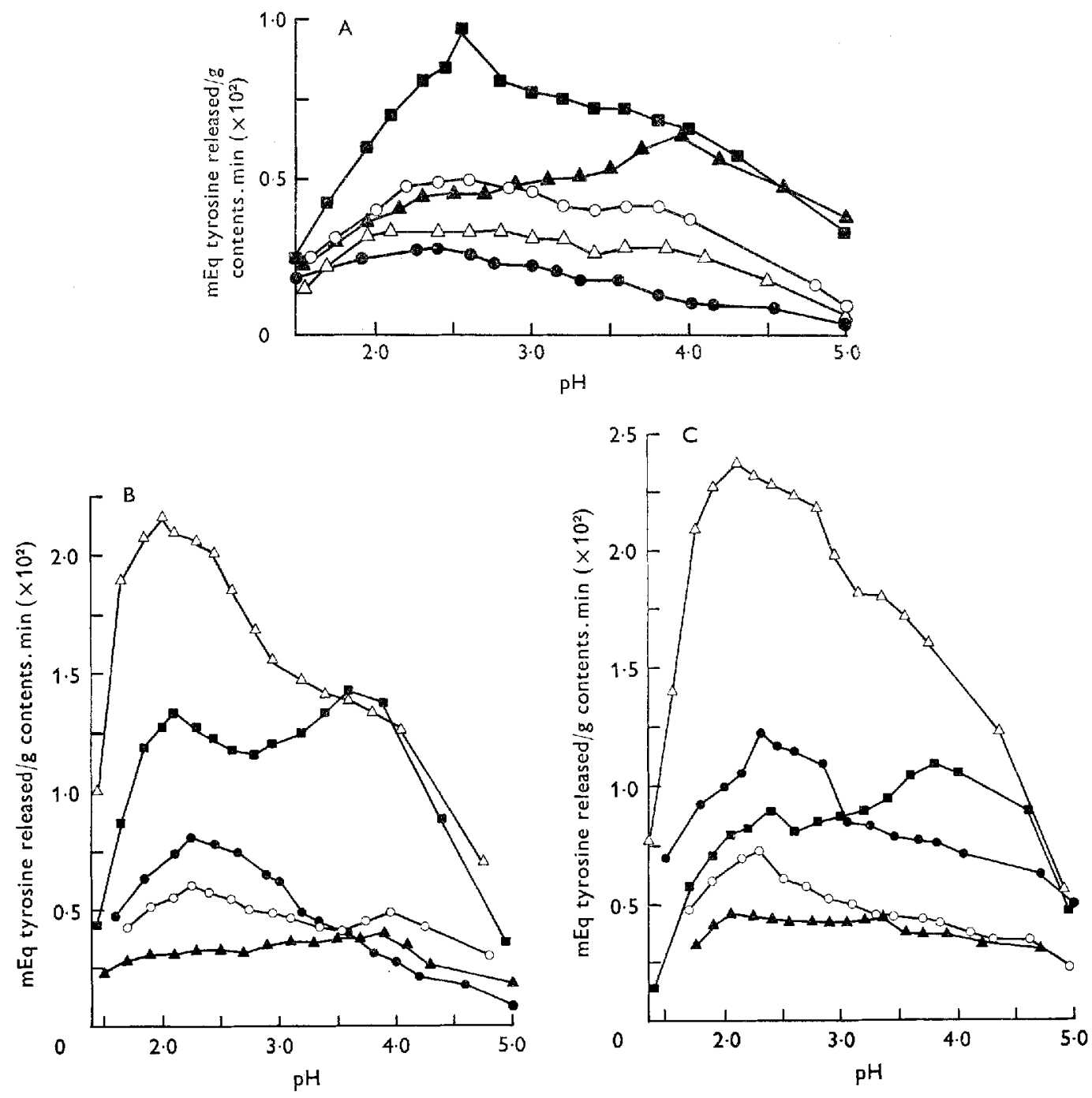

Fig. 2. pH-protcolytic activity curves for the abomasal contents of two Shorthorn $(O, \Delta)$ and three Ayrshire $(\bullet, \Delta, \mathbf{D})$ calves at mean ages of $(A, D) 9 \mathrm{~d},(\mathrm{~B}, \mathrm{E}) 26 \mathrm{~d}$ and $(\mathrm{C}, \mathrm{F}) 46 \mathrm{~d}$; $\mathrm{A}-\mathrm{C}$, before feeding; $\mathrm{D}-\mathrm{F}$, after feeding.

with the anti-pepsin serum whereas that of the mucosa of the neonate (spot $\mathrm{I}$ ) reacted only with the anti-rennin serum (Pl. $2 \mathrm{~B}$ ).

\section{DISCUSSION}

In the calf abomasum, the development of protease secretion did not follow a definite pattern except for a general increase with age in the total level of activity, and no breed difference was apparent between Shorthorn and Ayrshire calves. During the sampling period, both rennin and pepsin were secreted by all five calves, most of the rennin activity being seen after feeding. These results confirm the findings of 


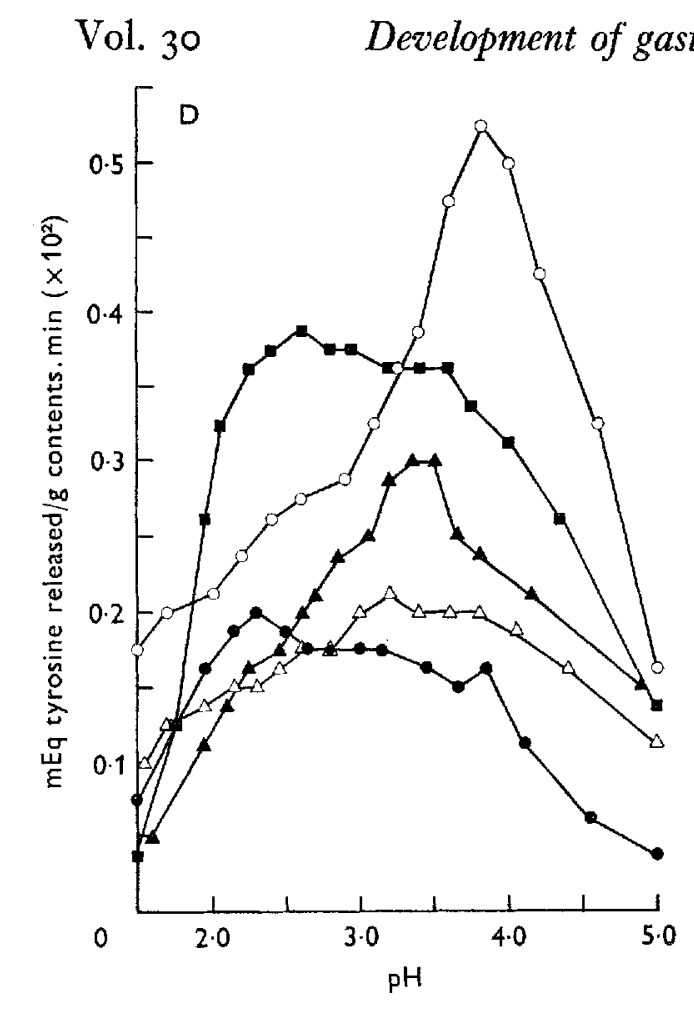

tric proteolytic activity
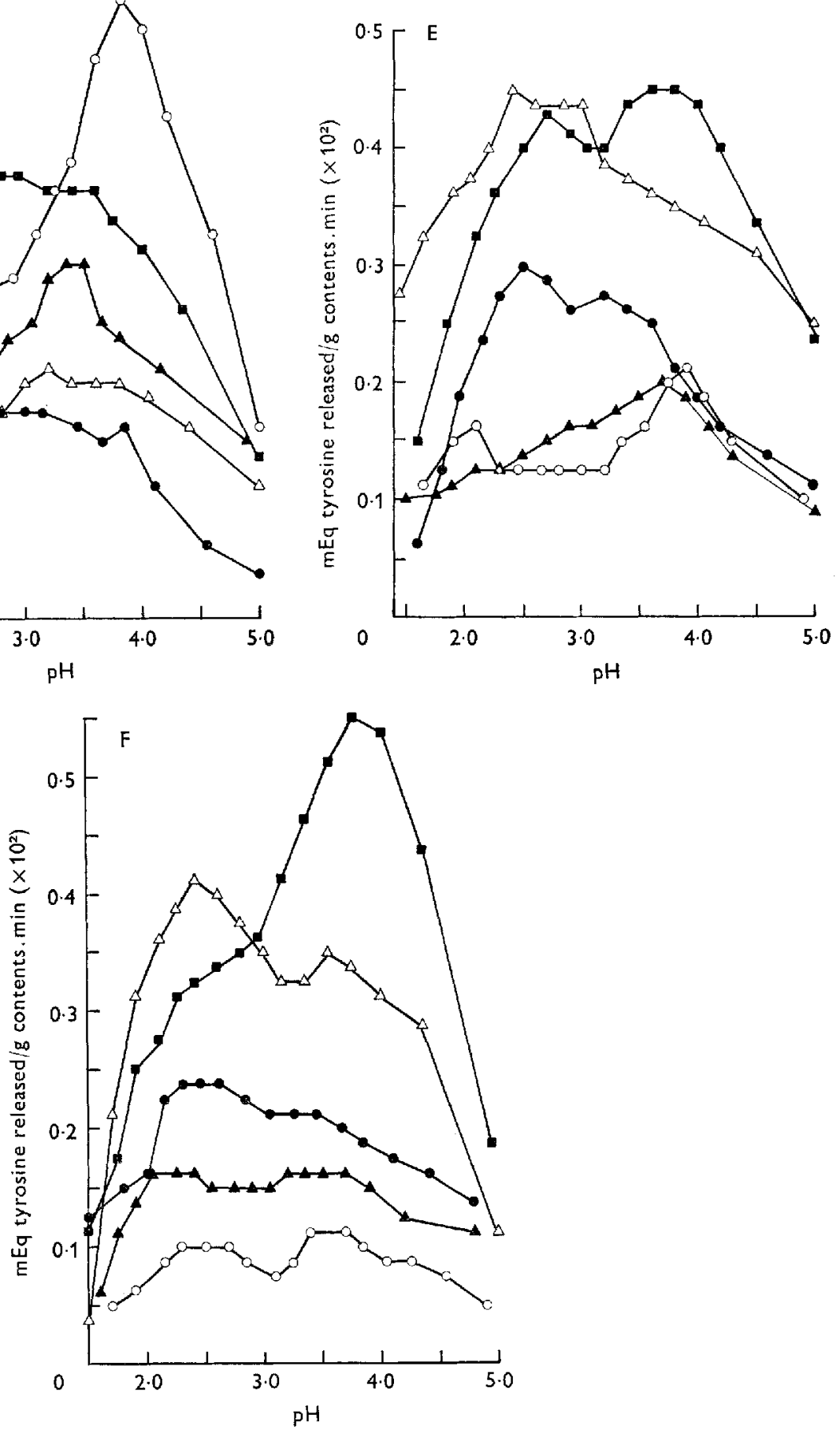

Fig. 2D-F. For legend see opposite. 


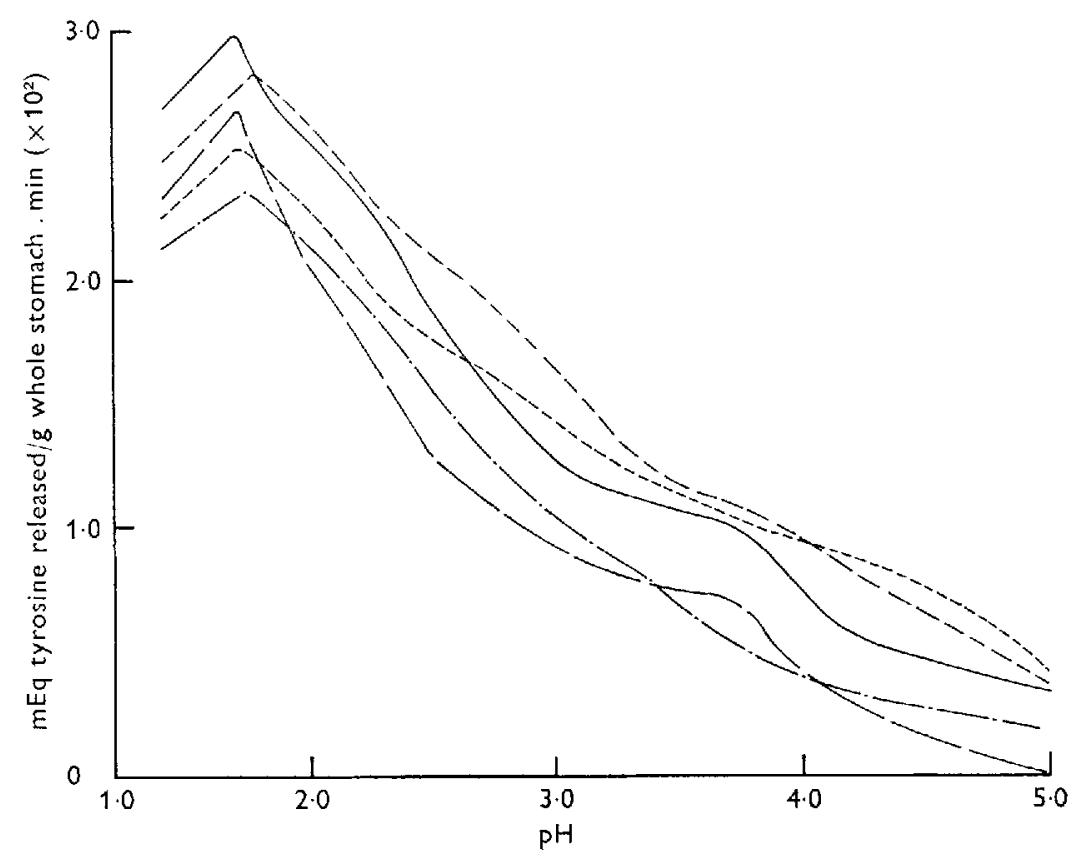

Fig. 3. Mean pH-proteolytic activity curves for the whole stomachs of guinea-pigs at birth $(--)$ and at $\mathrm{I}$ week $(-), 2$ weeks $\left(---_{--)}, 3\right.$ weeks $(--)$ and 4 weeks $(-\cdot-)$ of age.

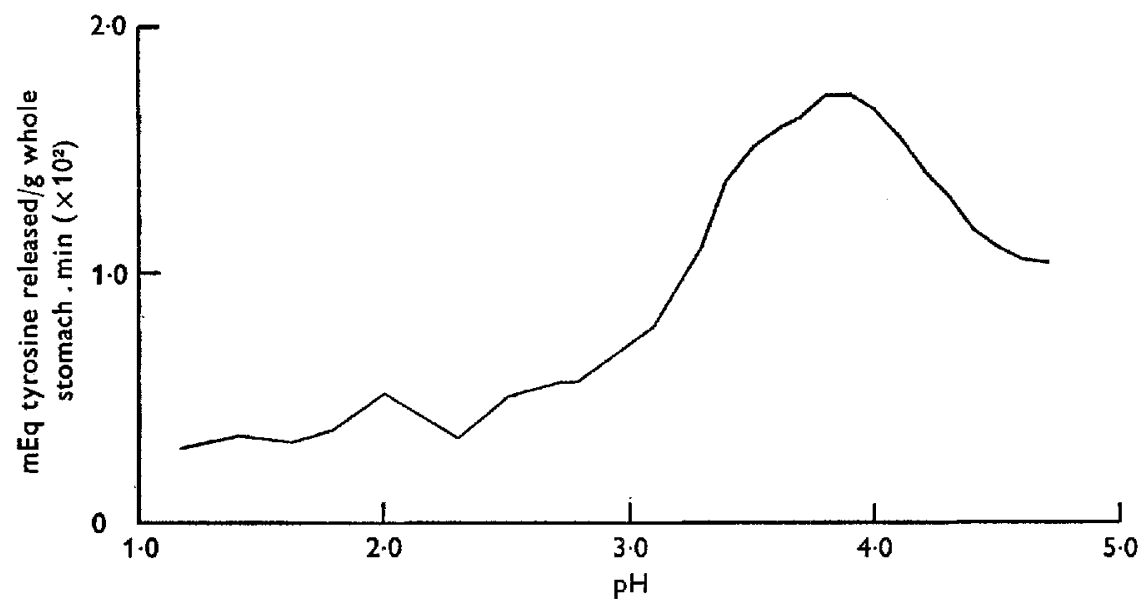

Fig. 4. Mean pH-proteolytic activity curves for the whole stomachs of rabbits at birth.

Henschel et al. ( $196 \mathrm{I}$ ), since the initiation of pepsin secretion was independent of the ingestion of roughage.

In the guinea-pig stomach, only pepsin activity was found at a consistently high level from birth. In contrast, the proteolytic activity of the rabbit stomach secretion was slow to develop. The level of activity in the stomach contents at I week of age was considerably lower than that found in the whole stomachs of the neonates. Of particular interest was the finding of a major peak of activity at $\mathrm{pH}_{3.5}$ in the stomachs 

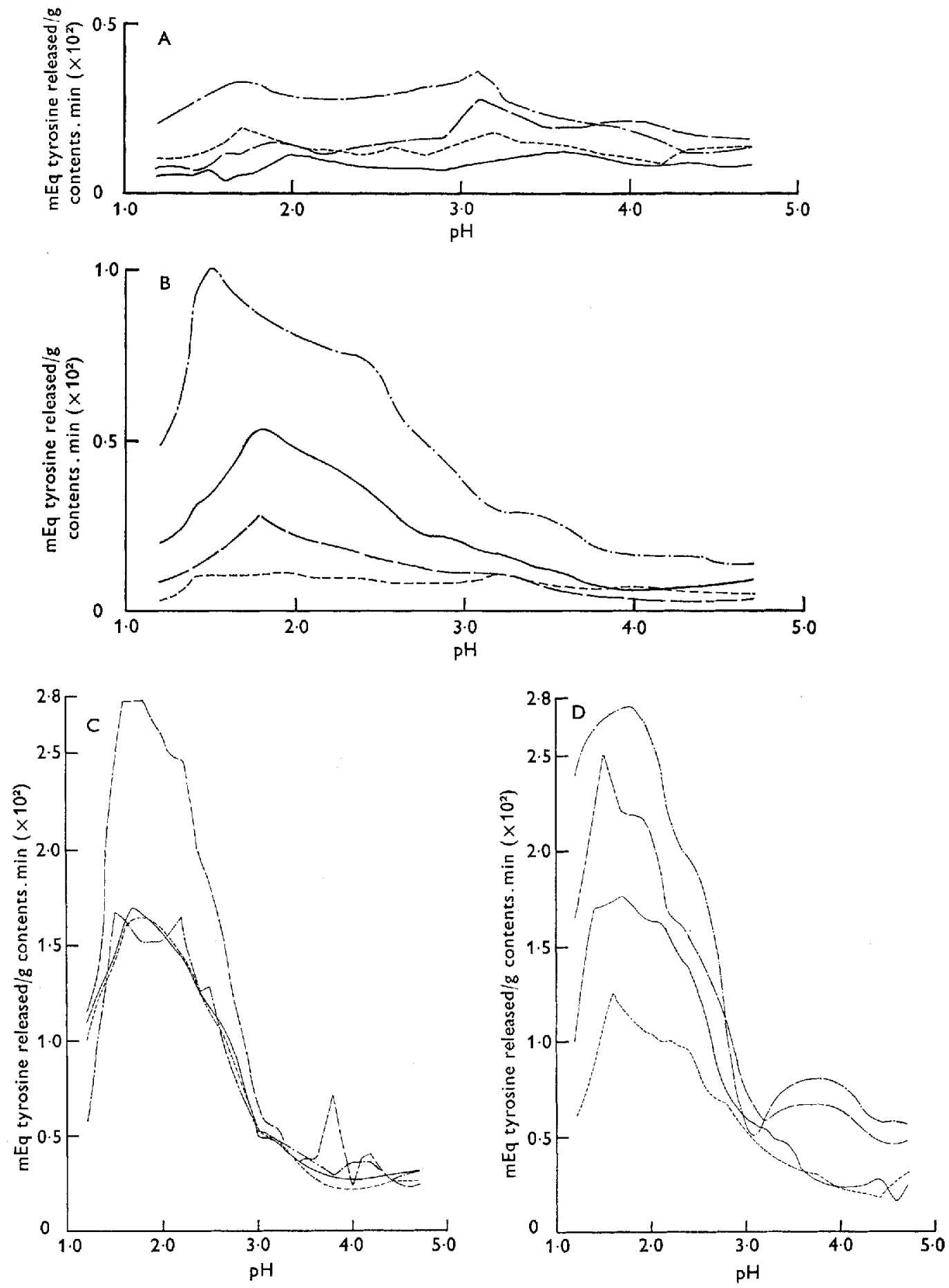

Fig. 5. pH-proteolytic activity curves for the stomach contents of individual rabbits at (A) I week, (B) 2 weeks, (C) 3 weeks and (D) 4 weeks of age. 


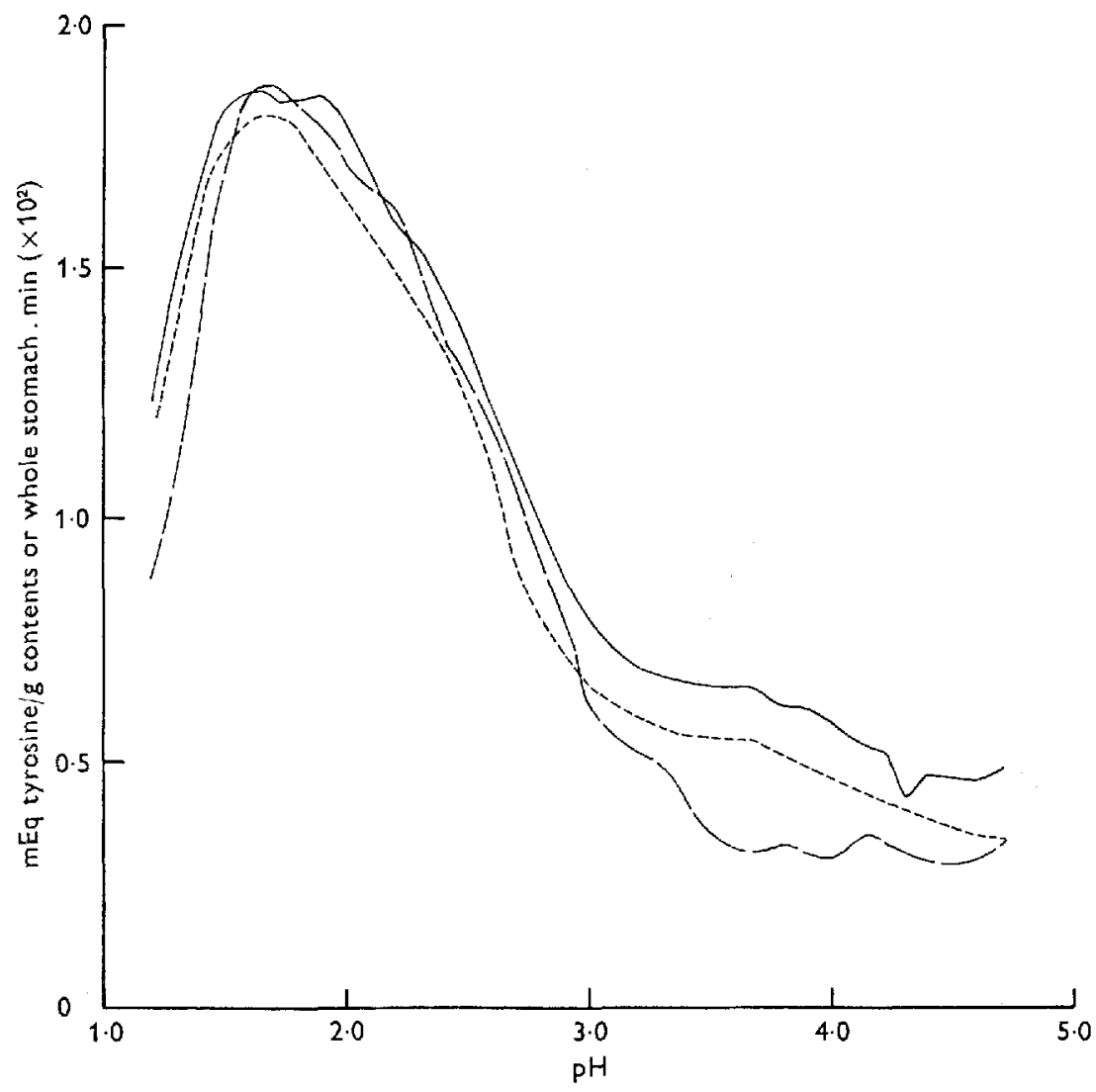

Fig. 6. Mean pH-proteolytic activity curves for the stomach contents of rabbits aged $3(-\longrightarrow)$ and $4(-)$ weeks, compared with the activity of whole stomachs of adult rabbits (- - - -).

at birth. Electrophoresis showed this activity to be due to two slow-moving components having mobilities similar to that of crystalline rennin. Immuno-chemical tests indicated that at least one of these was sufficiently close in structure to bovine rennin to react with its antiserum, whereas neither reacted with anti-pepsin serum.

Because of the existence of two peaks of activity in the rabbit stomach, protease secretion resembled that in the calf more than that in the guinea-pig, in which pepsin alone was secreted throughout the period. However, the pattern of development was more regular in the rabbit than in the calf, the differences within each age-group of rabbits being due to a difference in the total level of activity rather than to the variation in the pattern of secretion that was observed within the calf age-groups.

The slow appearance of true pepsin in the rabbit stomach secretion is surprising in view of the high level of protein contained in its milk. The evidence here tends to support the view that the inter-species differences found in the patterns of gastric protease secretion may reflect the relative states of maturity at which the young of these three species are born. It may be that weaning can normally take place only after the onset of the secretion of a true pepsin. The guinea-pig, which is born in an advanced state of development and can be weaned on to a solid diet within a few hours 
of parturition, secretes pepsin exclusively. When the highly immature rabbit pup is born, a rennin-like enzyme predominates. Weaning will normally start only after the end of the and week of life, by which time a pepsin has become the main gastric protease. The calf is born at a stage intermediate between that of the rabbit and that of the guinea-pig and here the pattern is confused, with variable amounts of pepsin and rennin being secreted. In the natural state, some roughage is ingested from an early age, but the development of the ability of the abomasum to digest solid food is normally complicated by the concurrent development of the rumen.

Activity in the rabbit stomach at the $\mathrm{pH}$ optimum of $2 \cdot 0$, which developed during the 2nd week of life, was shown to be due to two electrophoretically distinct components; the first, in the Etherington \& Taylor ( $\left.19^{67}\right)$ position 5, being developed earlier than the second, which was in position 3. Etherington \& Taylor (1967) equated pepsins in these positions respectively with 'parapepsin II' and 'pepsin' of Ryle \& Porter (1959), with the 'pyloric' and 'fundic' pepsins of Taylor (1959) and with the pepsins ' $C$ ' and ' $A$ ' of Ryle ( 1965 ). In the rabbit, pepsin 3 (fundic) was the main protease of the adult stomach, taking the same position as crystalline porcine pepsin, with the antiserum of which it cross-reacted. Even in the adult stomach mucosa, some activity was retained in the 6 and 7 positions, although of apparently insufficient strength to react with anti-rennin serum.

The identity of pepsin and rennin as two distinct enzymes appears still to be in some doubt; rennin is usually classified with pepsin. The report of the International Union of Biochemistry: Commission on Enzymes (1961) recommended the consecutive numbering systems $3 \cdot 4 \cdot 4 \cdot$ I, $3 \cdot 4 \cdot 4 \cdot 2$ and $3.4 \cdot 4 \cdot 3$ for pepsin, the 'parapepsins' and rennin, respectively, 'pepsin' referring to crystalline porcine pepsin and the 'parapepsins' being designated 'pepsin B'. Subsequently, different forms of pepsin have been discovered from different sources and their amino acid compositions, together with that of rennin, determined (Fruton, 1971). 'There are also differences in the behaviour of these different pepsins and of rennin towards certain synthetic substrates; these also are tabulated by Fruton (197r).

Hitherto, rennin has been regarded as being exclusive to the abomasum of the calf, and possibly of other ruminants. Should subsequent work establish the main gastric protease of the neonatal rabbit as a true rennin, this view will have to be revised.

I am grateful to Dr J. W. G. Porter for his helpful interest and advice. Thanks are due also to $\mathrm{Dr}$ A. T. Cowie for the fitting of the calf abomasal cannulas, to $\mathrm{Mr} \mathrm{W}$. B. Hill for the maintenance of the calves and the supply of guinea-pigs, to Mr E. V. Ruby and Mr D. A. F. Miles for the supply and maintenance of the rabbits, and to Miss P. A. Small for technical assistance. 


\section{REFERENCES}

Anson, M. L. (1939). F. gen. Physiol. 22, 79.

Berridge, N. J., Davis, J. G., Kon, P. M., Kon, S. K. \& Spratling, F. R. (1943). 7. Dairy Res. I3, I45. Berridge, N. J. \& Woodward, C. (1953). F. Dairy Res. 20, 255.

Deren, J. S. (1971). Am. F. clin. Nutr, 24, 144.

Etherington, D. J. \& Taylor, W. H. (1967). Nature, Lond. 2r6, 279.

Fruton, J. S. (1971). In The Enzymes Vol. 3, p. II9. [P. D. Boyer. editor]. New York and London: Academic Press.

Henschel, M. J., Hill, W. B. \& Porter, J. W. G. (r96r). Proc. Nutr. Soc. 20, xl.

Henschel, M. J. \& Porter, J. W. G. (Ig6r). Proc. Nutr. Soc. 2o, xxiii.

International Union of Biochemistry: Commission on Enzymes (196r). Report of the Commission on Enzymes of the Intemational Union of Biochemistry. Oxford: Pergamon Press.

Ryle, A. P. (1965). Biochem. 7. 96, 6.

Ryle, A. P. \& Porter, R. R. (1959). Biochem. F. 73, 75.

Taylor, W. H. (1959). Biochem. F. 71, 384 .

Turner, M. D., Miller, L. L. \& Segal, H. L. (I 967 ). Gastroenterology 53, 967.

Uriel, J. (1960). Nature, Lond. 188, 853 .

Van Slyke, L. L. \& Baker, J. C. (I918). F. biol. Chem. 35, 127.

\section{EXPLANATION OF PLATES}

\section{Plate I}

Agarose gel electrophoresis of extracts of mucosa from the stomachs of individual rabbits at different ages, compared with crystalline rennin and pepsin. $A$, crystalline rennin; $B$, neonatal rabbit mucosa; C, Io-d-old rabbit mucosa; D, crystalline porcine pepsin; $E$, 21-d-old rabbit mucosa; F, adult rabbit mucosa.

\section{Plate 2}

Immuno-diffusion of rabbit mucosal extracts against antiserums for pepsin and rennin.

(A) (anti-pepsin): 1 , neonatal rabbit mucosa; 2 , adult rabbit mucosa; 3 , crystalline rennin $(5 \cdot 0 \mathrm{mg} / \mathrm{ml})$; $4-6$, crystalline pepsin $(0 . \mathrm{I}, 0.5,1 \cdot 0 \mathrm{mg} / \mathrm{ml})$.

(B) (anti-rennin) : I, neonatal rabbit mucosa ; 2, adult rabbit mucosa; 3, crystalline pepsin ( $\mathrm{I} \cdot 0 \mathrm{mg} / \mathrm{ml})$; $4-6$, crystalline rennin $\left(0.5, \mathrm{I}^{\circ} \circ, 5^{\circ} \mathrm{0} \mathrm{mg} / \mathrm{ml}\right)$. 

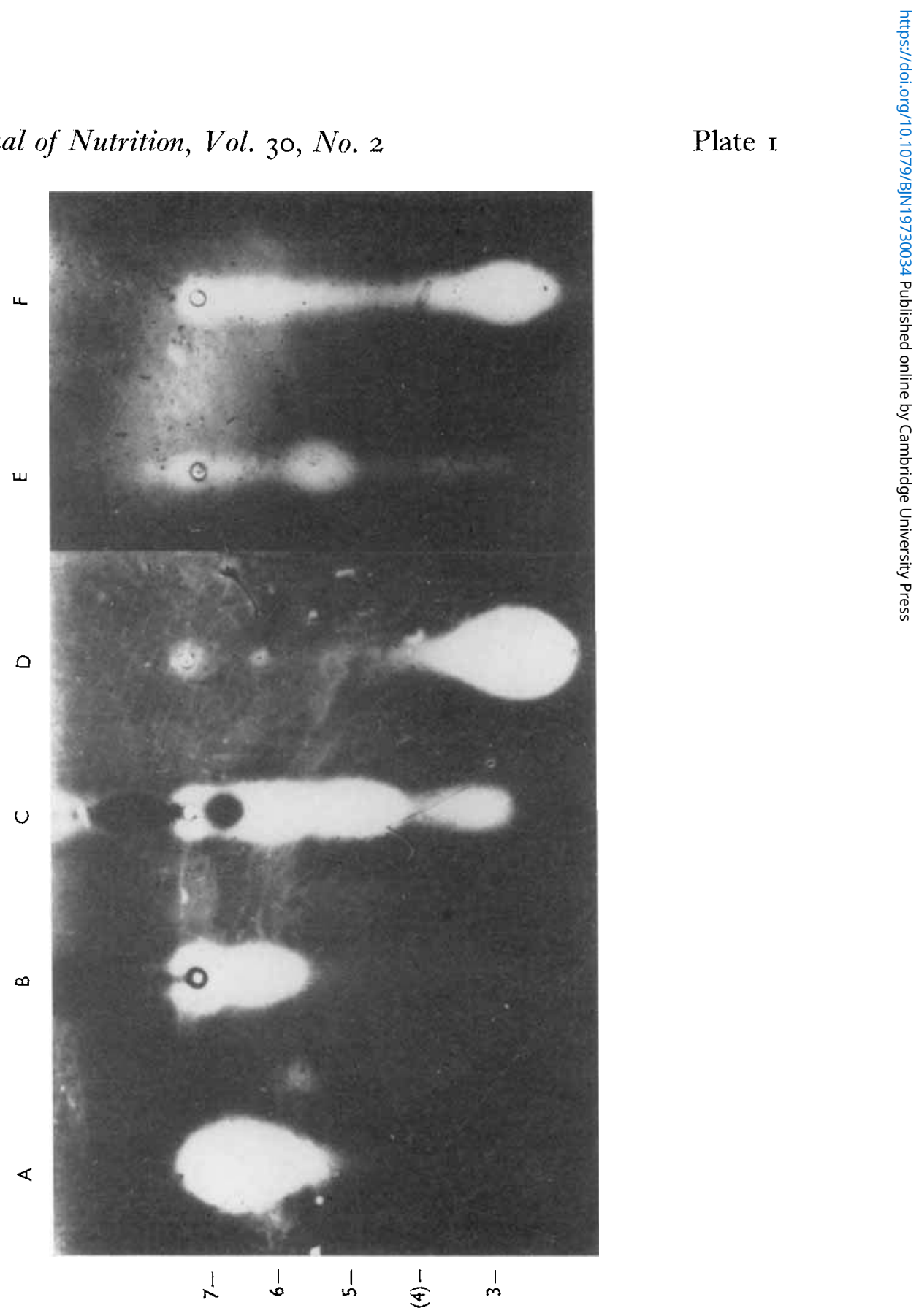

Etherington \& Taylor (1967) positions 
British Fournal of Nutrition, Vol. 30, No. 2

Plate 2
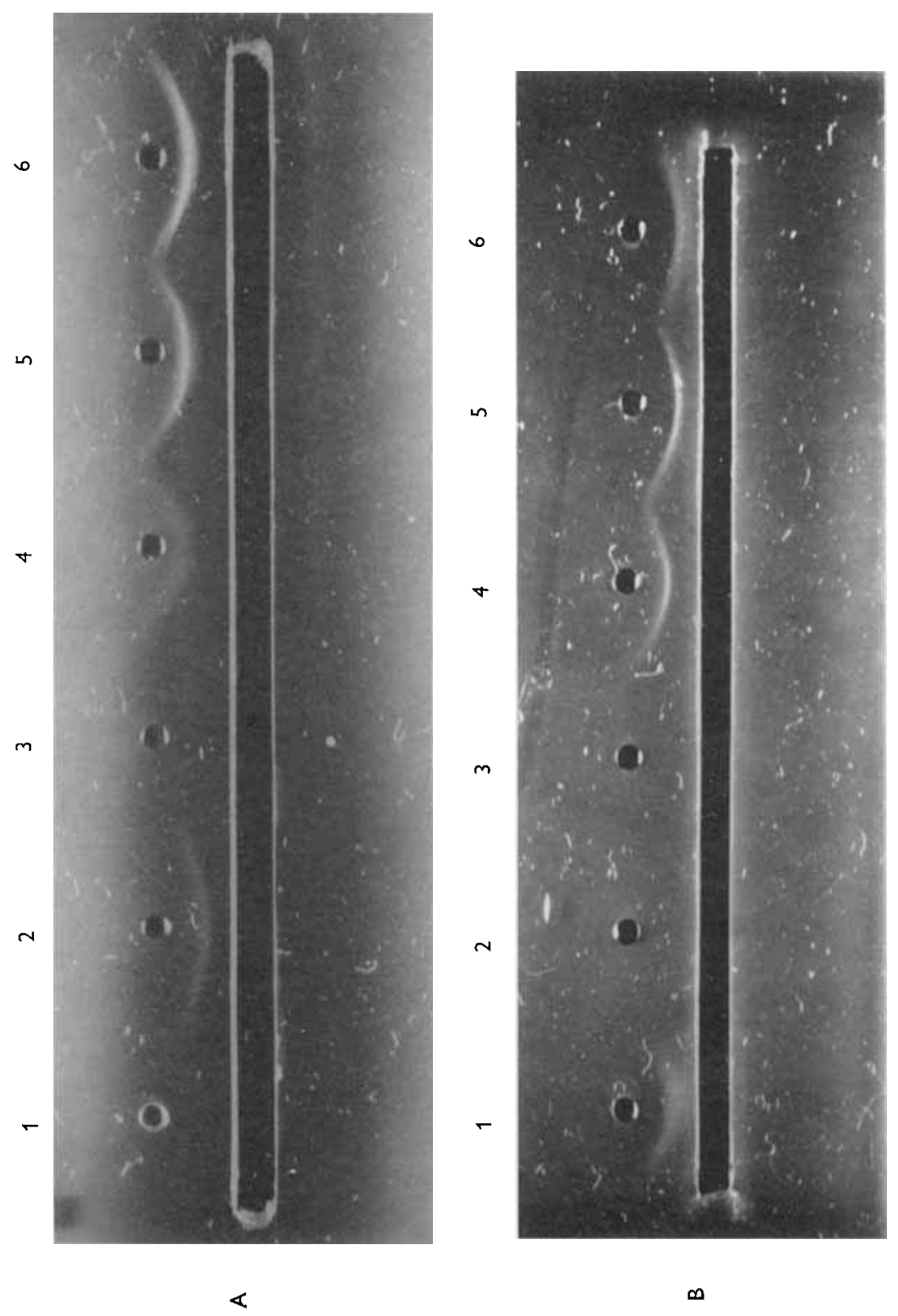

M. J. HENSCHEL 